\title{
3 Locating the Bantu conjoint/disjoint alternation in a typology of focus marking
}

\section{Introduction}

The Bantu conjoint/disjoint (CJ/DJ) alternation has attracted considerable attention in the recent (African) linguistics literature. The conjoint/disjoint alternation is found, for example, in Bemba (1) and Tswana (2), where the conjoint form cannot appear sentence-finally in main clauses, in contrast with the disjoint form, which can appear in a sentence-final position:

(1) Bemba
a. Tù-lòòndòlòl-à lyòònsé.
1PL.SM-explain-FV always
'We explain all the time.'
b. Tù-là-lòòndòlòl-à.
1PL.SM-DJ-explain-FV
'We (usually) explain.' (Kula this volume)

(2) Tswana
a. Kè-tlàà-bín-à lé èné.
1SG.SM-FUT-dance-FV with him/her
'I shall dance with him/her.'
b. Kè-tlàà-bín-á.
(DJ)
1sG.SM-FUT-dance-FV
'I shall dance.' (adapted from Creissels 1996: 110)

In Bemba, the alternation is indicated segmentally - the disjoint form in (1b) is marked by the marker -la-. In Tswana, whilst the alternation is marked segmentally in some tenses, in other tenses the marking is tonal (2). Several key

\footnotetext{
Jenneke van der Wal's part of this work is funded by the European Research Council Advanced Grant No. 269752 'Rethinking Comparative Syntax'. We would like to acknowledge our gratitude to Tim Bazalgette, Nancy Kula, and Thilo Schadeberg for discussion of some of the issues raised in this chapter.
}

DOI $10.1515 / 9783110490831-003$ 
aspects of the alternation have been shown to pose a challenge for a comprehensive analysis (see e.g. Hyman and by Van der Wal in this volume). These include the formal marking of the alternation and the relation with other prosodic markers of constituency, the restriction to specific tense-aspect paradigms, and the role of syntax and/or information structure in the distribution of the forms. In addition, there exists a high degree of micro-variation of conjoint/disjoint marking within Bantu, giving rise to typological and comparative-historical challenges.

Conjoint/disjoint systems have not been documented as such outside of Niger-Congo, and appear to be mostly found in Bantu languages, making the alternation geographically and typologically highly restricted. ${ }^{1}$ The aim of the present chapter is to locate the alternation within a wider typology of focus marking. This will enrich the broader research on focus by allowing it to draw on evidence from Bantu, as well as helping us to better understand the conjoint/ disjoint alternation through observed cross-linguistic parallels. It may also contribute to wider familiarity with the construction, and in doing so help to find instances of conjoint/disjoint systems outside of Niger-Congo.

For the purpose of the present study, we restrict our empirical scope to the expression of term focus, leaving aside for the time being focus on the verb or truth value (see discussion in Section 3). This allows us to establish the relevant typological space of our comparison through the use of two parameters: syntactic position and morphological marking. Syntactic position (or topology) has the four values left-peripheral, right-peripheral, immediately-before-the-verb (IBV) and immediately-after-the-verb (IAV), while morphological marking has the two values 'marking on the focused term' or 'marking on the verb' (while still marking term focus). Within this typology, typical Bantu conjoint/disjoint systems are characterised by combining focus marking on the verb and the use of the IAV position, while the systems of some other Bantu languages have only one of these two values: For example, Kinyarwanda shows focus on the verb but not IAV

1 Conjoint/disjoint alternations in Bantu languages such as Bemba (Sharman 1956; Costa and Kula 2008), Kirundi (Meeussen 1959) and Tswana (Creissels 1996) have been the most welldocumented cases; Kavari et al. (2012) note the similarity between conjoint/disjoint systems and 'tone cases' in Otjiherero - see also Hyman (this volume) on the comparison with tone cases, the augment and metatony. Non-Bantu languages for which conjoint/disjoint distinctions have been reported include Doyayo (Adamawa; Elders 2006), Igbo (and other Benue-Kwa languages) (Manfredi 2005), Majang (Nilo-Saharan; Joswig 2015), and Yom (Gur; Fiedler this volume). Although not explicitly referred to as conjoint/disjoint systems, comparable distinctions are also found in Bantoid (Aghem, Ejagham) and Nigerian Benue-Congo languages such as Efik and Gwari, where distinct verb forms are used to indicate argument vs. verb phrase focus (Hyman and Watters 1984). 
(focus is clause-final), and Aghem shows IAV, but (term) focus is marked on the term rather than on the verb. We extend the account to non-Bantu languages with the goal of interrogating whether additional patterns can be identified through the application of these parameters.

Based on a small convenience sample of sixteen Bantu languages and nine non-Bantu languages, we examine construction types in which focus is encoded through a combination of a dedicated focus position and the use of morphological marking, hence double marking. At present we do not include the third main focus coding strategy - prosody - since inclusion of prosody would make the study more complex than current space allows, and since we do not have sufficient information on prosodic marking for many of the languages included in our study. We do, however, include prosodic morphemes (such as grammatical tone marking the conjoint/disjoint distinction), as these fall within morphological marking. In terms of empirical scope, we adopt an inclusive approach to focus and focus marking, including data described as relating to focus in the literature, and including Bantu conjoint/disjoint systems from a variety of different languages. There is considerable variation between Bantu languages with respect to the function of conjoint/disjoint systems - some clearly relating to identificational focus, others clearly related to constituency, and some possibly performing a function which lies in between these two. A future study may well distinguish these different systems, as well as different kinds of focus more generally. However, for the present study, we include a wide selection of languages, based on formal criteria of morphological and syntactic marking, and develop a typology based on these. ${ }^{2}$ Overall, we show 1 ) that all eight logically possible combinations of topology and morphological marking are found in our sample, 2) that Bantu and non-Bantu languages occupy largely exclusive areas in the typological space, and 3) that, although this difference results to a large extent from the strong head-marking tendency in Bantu languages, the difference between Bantu and non-Bantu cannot be reduced to a single parameter.

The chapter is organised as follows. In Section 2, we introduce our typology of focus marking along with the parameters of syntactic position and morphological marking. In Section 3, we discuss methodological issues and the empirical limitations of the study, and provide a more detailed explication of the notion of focus we adopt. Section 4 presents a summary of our findings, based on our sample of 25 languages, discussing first non-Bantu languages and then Bantu languages, showing how the conjoint/disjoint alternation fits into this typological space. In Section 5, we present a summary of the discussion, draw a number of conclusions and identify possible directions for further research.

2 We provide a more detailed discussion of our working definitions and methodology in Section 3. 


\section{A typology of morphosyntactic focus marking}

A cross-linguistic comparison of how focus is expressed reveals a great deal of variation (see e.g. Foley 1994; Van Valin 1999; Drubig and Schaffar 2001; Büring 2010; Smit 2010). Generally speaking, focus can be expressed linguistically in prosody, morphology and/or syntax. Assuming that there is a unified conceptual notion of focus (cf. Molnár 2002; Neeleman et al. 2009; Zimmermann and Onea 2011), we examine a typology of focus marking along two parameters: syntactic position (or topology) and morphological marking. The former refers to focus marking through a dedicated syntactic position, and the latter to the use of dedicated morphological focus markers. The purpose of the current section is to present the parameters and illustrate their possible values in turn; further discussion on the definition and identification of focus follows in Section 3.

\subsection{Topology}

Many languages make use of a dedicated position for the expression of focus. A cross-linguistic comparison of the syntactic expression of focus reveals four possibilities for such a position: initial, immediately before the verb (IBV), immediately after the verb (IAV) and final. These are identified with respect to adjacency to the verb (IBV and IAV) or sentential edges (initial and final).

A sentence-initial focus position is illustrated in (3) with data from Hausa, an SVO language. Example (3a) shows an instance of basic word order with a neutral information structure. In (3b) teelà 'tailor' is in focus and placed in a sentenceinitial position. ${ }^{3}$

(3) Hausa
a. Bintà zaa tà biyaa teelà.
B. FUT 3SG.F pay tailor
'Binta will pay the tailor.'
b. Teelà (nee) Bintà zaa tà biyaa.
tailor FOC B. FUT 3SG.F pay
'Binta will pay the TAILOR.' (Hartmann and Zimmermann 2007: 99)

Ostyak (Uralic, SOV) has an IBV focus position as shown in (4). Example (4a) shows that a wh-question word corresponding to the passive agent adjunct must

3 In example (3b) the term in focus can optionally be followed by the masculine focus marker nee. 
occur in the IBV position. In (4b) the same is shown for a wh-question word corresponding to the indirect object, while (4c) shows that the focused element in the answer to (4b) also obligatorily occurs in the IBV position:

(4) Ostyak

a. $\left({ }^{*} X o j-n a\right)$ tam a:n xoj-na tu:-s-a? who-LOC this cup who-LOC take.away-PAST-3SG.PASS

'Who took away this cup?'

b. ( ${ }^{*}$ Xoj e:lti) tăm a:n xoj e:lti ma-s-e:n? who to this cup who to give-PAST-2SG.OM2

'To whom did you give this cup?'

c. (*Juwan-a) tam a:n Juwan-a ma-s-e:m.

John-LAT this cup John-LAT give-PAST-1SG.OM2

'I gave this cup to John.' (Nikolaeva 2001: 18)

The use of the IAV focus position can be seen in Aghem (Grassfields Bantu, Cameroon). In examples (5a) and (5b) the focused term, án ${ }^{\downarrow}$ sóm and áfín respectively, is placed immediately after the verb. ${ }^{4}$ Since the canonical word order in Aghem is $\mathrm{S}(\mathrm{Aux}) \mathrm{VOX}$, the non-canonical position of the adverbial and the subject show that IAV is a dedicated focus position.

(5) Aghem

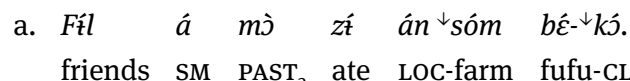

'The friends ate fufu in the FARM.'

b. $\grave{A}$ mò ż́ á-fín $b \hat{\varepsilon}^{\downarrow}{ }^{\downarrow} k j$ án ${ }^{\downarrow}$ sóm.

ES $\mathrm{PAST}_{2}$ ate friends fufu-CL LOC-farm

'The FRIENDS ate fufu in the farm.' (Watters 1979: 144, 147)

Final focus position can be seen in Tangale (Chadic, Nigeria, SVO) with focused subjects. Example (6a) shows a wh-question word and (6b) shows a focused subject appearing in the clause-final position.

4 The term IAV was first used by Watters (1979). In addition to this focus position, Aghem also uses verbal and auxiliary marking to express focus. This is discussed in further detail below. Watters (1979: 148-152) also identifies an immediately before the verb (IBV) position in Aghem which may host presupposed material. 
(6) Tangale
a. Pàd-gò tàabéè nóy?
buy-PERF tobacco who
'Who bought tobacco?'
b. Pàd-gò tàabéè kài.
buy-PERF tobacco Kai
'KAI bought tobacco.' (Kidda 1993: 131 via Zimmermann 2011: 1173)

This gives us Table 1, which illustrates our first parameter and contains languages in which one of the four focus positions can be identified:

Table 1: Topology parameter and its values.

\begin{tabular}{lllll}
\hline Topology & Initial & IBV & IAV & Final \\
\hline & Hausa & Ostyak & Aghem & Tangale \\
\hline
\end{tabular}

\subsection{Morphological focus marking}

Some languages make use of morphological markers for the expression of focus. Morphological focus marking can involve the attachment of a focus marker on the focused term itself, or on the verb, either of which can express a focused interpretation of a term, i.e. an argument or adverb but not the predicate. ${ }^{5,6}$

The following data from Sri Lankan Malay illustrate morphological focus marking on the term. In (7) an enclitic -jo is suffixed to participants which appear in their canonical position:

(7) Sri Lankan Malay

a. (So, [while] the king was planning to make a fool out of Andare)
Raja=jo su-jaadi enco.
king=FOC PST-become fool
'The KING (himself) became a fool.'

\footnotetext{
5 Marking on the term could be considered analogous to dependent-marking while marking on the verb could be considered as head-marking. However, these terms typically refer to syntactic relations in the clause, rather than to information structural properties and the relation between terms and the wider discourse structure, and so we chose not to employ this terminology here. 6 It is logically possible, although appears to be rare, to have morphological marking on both the term and the verb. This can be seen in the optional term marking in the Colloquial Sinhala examples in (8), in Aghem (Hyman and Polinsky 2009), Yom ('background tense', Fiedler this volume) and Baynunk (Robert 2010).
} 
b. (Now that we've done all this)

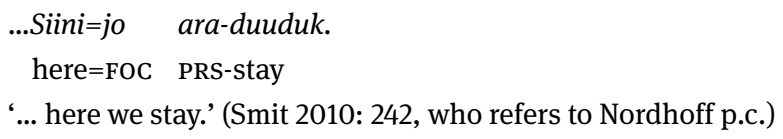

Verb-marking term focus is encountered in Colloquial Sinhala. In a neutral context the final vowel of the verb is $-a(8 \mathrm{a})$, but when a pre- or post-verbal term is in focus, the verb ends in the vowel $-e$, as in (8b) and (8c). The focused term can have additional marking, but this is said to be optional, whereas the marking on the verb is obligatory (Slade 2011: 61).

(8)

$$
\begin{aligned}
& \text { Colloquial Sinhala } \\
& \text { a. Mamə gaməțə yann-a. } \\
& \text { 1SG.NOM village-DAT go.PRES-NFOC } \\
& \text { 'I go to the village.' } \\
& \text { b. Mamə gaməțə(-y) yann-e. } \\
& \text { 1SG.NOM village-DAT(-EMPH) go.PRES-FOC } \\
& \text { 'It is to the village I go.' } \\
& \text { c. Mama yann-e gamațə(-y). } \\
& \text { 1SG.NOM go.PRES-FOC village-DAT(-EMPH) } \\
& \text { 'It is to the village I go.' (Slade 2011: 63, 64, adapted) }
\end{aligned}
$$

Our second parameter, morphological marking (of term focus), can thus be set as 'on the focused term' or 'on the verb' as indicated in Table 2.

Table 2: Morphological focus-marking parameter.

\begin{tabular}{clc}
\hline $\begin{array}{c}\text { Morphological focus } \\
\text { marking }\end{array}$ & $\begin{array}{l}\text { On focused term } \\
\text { Sri Lankan Malay }\end{array}$ & $\begin{array}{c}\text { On verb } \\
\text { Sinhala }\end{array}$ \\
\hline
\end{tabular}

\subsection{Combination of syntactic and morphological focus marking}

So far we have looked at syntactic and morphological strategies as logically independent means of focus marking. We have discussed them separately showing a single focus-marking mechanism (topological or morphological) per language. With the conjoint/disjoint systems in mind, however, we are interested in the combination of syntactic and morphological means for the expression of focus. 
Table 3: Parametric settings for the expression of focus.

\begin{tabular}{|l|l|l|l|l|}
\hline Morphology Topology & Initial & IBV & IAV & Final \\
\hline On term & & & & \\
\hline On verb & & & & \\
\hline
\end{tabular}

If we merge the two previously shown tables (Tables 1 and 2), we obtain eight possible ways in which syntactic and morphological strategies can be combined as shown in Table 3.

Table 3 is to be filled with languages which show a focus-marking strategy involving the simultaneous use (optional or obligatory) of syntactic and morphological means for marking term focus. Note that we do not claim that the constructions we are discussing are the only strategies for the realisation of focus in a given language, rather we aim to show a cross-section of strategies in different languages without implying an exhaustive description.

Having introduced the typological parameters established for the purpose of this study, we turn now to our methodology (Section 3) before proceeding to our findings and outlining the typological context within which the conjoint/disjoint systems will be discussed (Section 4).

\section{Methodology, empirical focus and scope of the study}

Some of the methodological issues that need to be addressed concern definitions, sample choices, the inclusion and exclusion of different kinds of data, and possible limitations of the study. In particular, we will discuss our empirical concentration on term focus (rather than predicate-centred focus), and on morphological and syntactic encoding of focus (rather than prosodic encoding), as well as the particular kinds of focus constructions we have included. It is also worth noting that our sample of languages is a convenience sample, without any claims of balance or exhaustiveness. In selecting languages, we were mainly guided by previous comparative, descriptive or theoretical studies, and our primary aim was to establish a typological space within which to locate conjoint/disjoint systems, without taking into account the frequency or representativeness of different constructions (although this would obviously be an interesting point for further research). 


\subsection{Term focus vs. predicate-centred focus}

As shown by the data discussed in the preceding section, we are comparing the Bantu conjoint/disjoint alternation with cross-linguistic variation in marking of term focus, as opposed to verb or predicate-centred focus (including polarity, TAM and verb focus, and other forms of focus related to the predicate or the clause; Güldemann 2009, also Morimoto this volume). In some sense, this is only half the relevant context, as conjoint/disjoint systems have often been related to both term focus (i.e. marking a following constituent as being in focus) and predicate focus (i.e. marking the predicate itself as being [included in] the focus) (cf. Hyman and Watters 1984; Güldemann 1996, 2003; Nshemezimana \& Bostoen this volume; Voeltz 2004). Nevertheless, there is a clear correlation between the use of the conjoint verb form and a term being (part of the) focus, whereas it is not the case that each occurrence of the disjoint verb form results in predicate-centred focus (but see Nshemezimana \& Bostoen this volume). This is one motivation for first examining the expression of term focus. Secondly, there is more readily available literature on term focus, and so it is easier to establish the typological background and variation of term focus. In contrast, typological variation of predicate-centred focus is more restricted - or possibly less well described - with the major patterns being marking of the predicate by stress, or some form of reduplication (cf. e.g. Aboh 2004; Güldemann et al. 2014), neither of which is directly relevant for attested conjoint/disjoint systems. So, while a more detailed study of variation in predicate-centred focus marking, and its relation to conjoint/disjoint systems would be worthwhile undertaking in the future, for the purposes of the present chapter, we restrict our investigation to term focus and the way(s) in which this is expressed morphologically or syntactically across different languages.

\subsection{Morphological/syntactic vs. prosodic encoding of focus}

A second restriction of our sample is that we are only looking at morphological and syntactic marking of focus, disregarding prosodic marking. As with the concentration on term focus, this decision is partly driven by operational reasons: Morphological and syntactic marking of focus are better described overall. We also wish to exclude from the study languages in which focus is marked solely through prosody. We therefore concentrate on languages which mark focus morphologically, while making no claims that these languages do not also employ prosodic mechanisms for information structure purposes. 
The relation between focus and prosody is well established in languages like English and Italian, where the difference between the two languages is often analysed as a difference between fixed word order and variable prosodic prominence in the sentence in English as opposed to prosodic prominence, fixed stress and variable word order in Italian (see Zubizarreta 1998; Lambrecht 1994; Vallduví 1992; Van Valin 1999; Samek-Lodovici 2005; Büring 2010; among others). However, in many Bantu - and indeed African - languages, stress or corresponding forms of prosodic prominence such as vowel lengthening do not play a direct role in focus marking (cf. Hyman 1999; Zerbian 2007; Downing 2013, see also other Chapters in this volume, especially by Kula, by Halpert, and by Zeller, Zerbian \& Cook).

To illustrate, in Chichewa, prosodic prominence (penultimate lengthening) is assigned to the penultimate syllable preceding an intonation phrase boundary. It typically occurs clause-finally, but may also occur, for example, on preverbal topics, and so prosodic prominence can be assigned to several constituents in the clause. Furthermore, no word order change needs to occur in Chichewa to express focus: Both prominence and word order can remain invariant, and so focus can remain unmarked. Penultimate lengthening in (9) can be seen with the topic mwaâná 'child', which is (optionally) phrased as extra-clausal, and with the final constituent mwáálá 'rock'. Crucially, there is no prosodic marking (stress or lengthening) on the focused constituent nyumbá 'house', indicating that penultimate lengthening is not directly related to focus.

(9) Chichewa

Mw-aáná á-naa-ménya nyumbá ndí mwáálá.
1-child 1SM-TAM-hit 9.house with 3.rock
'The child hit THE HOUSE with a rock.'
(Answer to 'What did the child hit with the rock?')
(Downing and Pompino-Marshall 2013: 661)

Since Chichewa, unlike other Bantu languages, also does not have a syntactic IAV position or conjoint/disjoint verb forms, focus is not marked in this example.

Furthermore, Cheng and Downing (2009) argue that even in Bantu languages which exhibit a focus-related word order change - such as the use of the IAV position in $\mathrm{Zulu}$ - underlyingly, word order change is not directly related to prosodic prominence, although the focused constituent may attract prosodic marking by virtue of being phrase-final. In (10), the focused phrase is VP-final, and the following NP inkukhu 'chicken' is right-dislocated, as indicated by the co-referential object marker on the verb form. 
(10) Zulu

a. (Ú-si:pho) (ú-yí-phékéla ba:ni) (ín-ku:khu). 1-Sipho 1SM-9oM-cook.for 1.who 9-chicken

'Who is Sipho cooking the chicken for?'

b. (Ú-síph' ú-yí-phékél' ízí-vakâ:sh') (ín-ku:khu).

1-Sipho 1sM-90M-cook.for 8-visitor 9-chicken

'Sipho is cooking the chicken for the visitors.' (Downing 2013: 34)

The absence of a direct relation between focus and prosodic marking has, in part, informed our decision to set prosodic marking to one side, and to concentrate on morphological and syntactic expression of focus for the present study. ${ }^{7}$ Research building on this initial typology could involve prosodic marking of focus.

\subsection{Focus}

In comparing the variation in the expression of term focus, we must define what we mean by 'focus' and how we establish whether a certain linguistic strategy expresses focus. We adopt a broad definition of focus, including both 'new information' and contrastive or identificational focus (compatible with Dik's 1997 focus and subtypes, see also Lambrecht 1994; É. Kiss 1998; Krifka 2007). Although many of the examples below have a clear contrastive or identificational interpretation, in other cases we have to rely on secondary sources where 'focus' is underspecified. It may thus be the case that we can or should employ a more narrow definition of focus, but for now we need to keep it broad. Furthermore, even though it may turn out in more detailed research that 'contrast' should be taken as a separate notion (Molnár 2002, Neeleman et al. 2009), for this comparative overview we do not examine it separately.

In Section 2 we saw examples of a dedicated focus position and of focus-marking morphology. The question arises as to how we can determine whether a certain position or morphological marking actually indicates focus. As Matić and Wedgwood (2012) point out, it may be that the relevant strategy does not actually encode focus, and that focus interpretation is a side-effect of some other mechanism (i.e. a pragmatic implicature).

7 It has to be kept in mind here that conjoint/disjoint marking is often tonal, i.e. often involves assignment of different verb tones, but that in that case, the marking is morphological (through tonal morphemes) rather than attributable to phrasal prosodies. 
While keeping this in mind, and in part having to rely on the authors' description of a phenomenon as 'marking focus', we have three well-established diagnostics to check for focus: question-answer pairs, wh-words, and focus particles (see Van der Wal 2016 for further focus diagnostics and for detailed references). These are the contexts and tests that we will see in the examples in Section 4, when discussing focus positions and morphology in the various languages. In the current section, the tests are discussed in turn and illustrated for Makhuwa, which has an IAV focus position (topology) and the conjoint/disjoint alternation (morphological marking on the verb).

A well-known and widely accepted diagnostic for focus is question-answer pairs. Essentially, a wh-question always asks for new information. If focus is defined as the new information in a sentence, then it follows that in the answer to a wh-phrase - the phrase that replaces the wh-element - is in focus:

Q-A test (Kasimir 2005: 12)

If a question asks for some $\mathrm{X}$ ( $\mathrm{X}$ being a syntactic category), in a direct answer to this question, the constituent which corresponds to $\mathrm{X}$ is focused.

If the NP that forms the answer to a wh-question must be located in a specific position and is ungrammatical elsewhere, this can be taken as evidence that the position is a dedicated focus position. In Makhuwa, answers to non-subject wh-questions must occur in the IAV position, possibly resulting in topical elements being moved to the preverbal domain: ${ }^{8}$

Makhuwa

a. O-n-thum-el-alé páni ekúwo? 1SG.SM-10M-buy-APPL-PFV.CJ 1.who 9.cloth 'Who did you buy a cloth for?'

b. (Ekúwó) ki-n-thum-el-alé Ańsha. 9.cloth 1SG.SM-10M-buy-APPL-PFV.CJ 1.Ansha 'The cloth, I bought for Ansha.' (database Van der Wal)

In the same way, morphological marking can also be tested: If a focused reading is only possible with a particular morphology, then this morphology can be said to encode focus. This is shown in (13), where the verb in the answer necessarily appears in the conjoint form in order to be appropriate: ${ }^{9}$

8 Note that Makhuwa has as a neutral order theme > benefactive, which is unusual for Bantu languages. See also Van der Wal (2009).

9 The conjoint or disjoint form of the verb is indicated in the gloss and before the example. 
(13) Makhuwa
a. CJ O-lomw' éshéeni?
1SM-fish.PFV.CJ 9.what
'What did he catch?'
b. CJ O-lomwé ehopá.
1SM-fish.PFV.CJ 9.fish
'He caught fish.'
c. DJ \# Oo-lówá ehópa.
1SM.PFV.DJ-fish 9.fish
'He caught fish.' (Van der Wal 2009: 232)

A second diagnostic are the wh-words themselves. Wh-words very often pattern with focus, and hence if wh-words are restricted in their occurrence to a certain position or must occur with a certain morphology, this forms evidence for a dedicated focus position and dedicated focus morphology, respectively. In Makhuwa, non-subject wh-words must occur in the IAV position, as shown in (14) and they must occur with the conjoint verb form (15):

(14) Makhuwa
a. CJ O-n-rúw-áka tsayi eshíma?
2SG.SM-PRES.CJ-stir-DUR how 9.shima
'How do you make shima?'

b. CJ ${ }^{\star} O$-n-rúw-áka eshímá tsayí?

(Van der Wal 2009: 225)

(15) Makhuwa
a. CJ $O-n-c$ éshéeni?
2SG.SM-PRES.CJ-eat 9.what
'What are you eating?'
b. DJ *O-náâ-ca eshéeni?
(Van der Wal 2009: 231)

A difficulty here is that interrogatives do not pattern with focus in every language. In our sample, Kirundi shows a final focus position (16) but wh-words can appear in situ rather than in the final position (17). This does not invalidate interrogatives as a heuristic for focus, but does bring a warning that it is not a conclusive test and more than one diagnostic should be applied (cf. Aboh 2007). 
(16) Kirundi Muduga 1sM-F.PAST-give AUG-2-child AUG-7-book 'Muduga, he gave the children A воок.'
a. DJ Mudúga, $y$-a-hâye $a$-b-âna i-gi-tabo.
b. CJ Mudúga, y-a-hâye i-gi-tabo a-b-âna. Muduga 1SM-F.PAST-give AUG-7-book AUG-2-child 'Muduga, he gave THE CHILDREN a book.' (Sabimana 1986: 91)

(17) Kirundi
CJ Y-a-zan-i-ye
ndé u-mu-pira?
1SM-R.PAST-bring-APPL-ASP who AUG-3-ball

'For whom did she bring a ball?' (Sabimana 1986: 193)

A third diagnostic are so-called focus particles or focus-sensitive operators. These trigger a focused reading on the element they modify, or associate with the focus of the sentence. Common focus particles include scalar 'even', additive 'also', and exclusive 'only' (see Van der Wal 2014 for further discussion of this diagnostic). If an element modified by such a particle is distributionally restricted to a certain position, or must occur with a certain morphology, this again shows that there is a dedicated focus position or dedicated focus morphology. The Makhuwa data show that an NP with the exclusive particle paáhí 'only' must appear in IAV position (compare (18a) and (18b)), and it must follow a conjoint form, not a disjoint form (18c).

$$
\begin{aligned}
& \text { Makhuwa } \\
& \text { a. CJ Maríyá o-m-vah-alé [ekamitsa paáhí] [Apútáála]. } \\
& \text { 1.Maria 1sm-10M-give-PFV.CJ 9.shirt only 1.Abdallah } \\
& \text { 'Maria gave Abdallah only a shirt.' } \\
& \text { b. cJ ?? Maríyá o-m-vah-alé [Apútáálá] [ekamitsa paáhi]. } \\
& \text { 1.Maria 1SM-10M-give-PFV.CJ 1.Abdallah 9.shirt only } \\
& \text { 'Maria gave Abdallah only a shirt.' } \\
& \text { c. DJ * Maríyá o-ḿ-váhá [ekamitsa paáhí] [Apútáála]. } \\
& \text { 1.Maria 1SM.PFV.DJ-10M-give 9.shirt only 1.Abdallah } \\
& \text { 'Maria gave Abdallah only a shirt.' (Van der Wal 2009: 226) }
\end{aligned}
$$

There is a crucial difference between these focus particles, which carry some semantic value (scalar, additive, exclusive) and what we call focus markers, which are purely functional morphological markers of focus. This latter type is illustrated by data from Gungbe, where the marker wè marks focus on the preceding element, cf. (19b) and (19c). The particle and the marker can actually co-occur, as shown in (19d). 
(19) Gungbe
a. Séná xìa wémà.
Sena read.PERF book
'Sena read a book.'
b. Sćná \#(wè) xìá wémà.
Sena FOC read.PERF book
'SENA read a book.'
c. Wémà *(wè) Sćná xìa.
book FOC Sena read.PERF
'Sena read a воок.'
d. Wémà ló co ${ }^{*}(w \bar{c})$ Séná xìá.
book DET only FOC Sena read.PERF
'Sena read only the book.' (Aboh 2004 and personal correspondence)

Two issues arise with respect to establishing what constitutes a focus-marking strategy, whether topological or morphological. The first concerns the strictness of the focus marking. For topology, it is hardly ever the case that all focused NPs can appear in the focus position. For example, the IAV position in Makhuwa can only express focus on objects and adverbs; subjects are ungrammatical in the position directly following a conjoint verb form (Van der Wal 2009). Subjects in Makhuwa can only be focused in a cleft sentence. Another example of a non-strict focus position is when elements other than the focused one seem to have priority. In Turkish, for example, which has been characterised as a language with an IBV focus position (Butt and King 1996), ${ }^{10}$ indefinite nouns also need to occur in the IBV position and they apparently take priority over (focused) wh-words, as illustrated in the examples in (20) below.

(20) Turkish
a. Kim para al-dit?
who money steal-PAST
'Who stole (some) money?'
b. $\quad \star$ Para kim čal-dí?
money who steal-PAST
'Who stole (some) money?'

10 See also Göksel and Özsoy (2000), who argue that focused constituents can appear in any preverbal position. 


\section{c. Para-yi kim čal-dit? \\ money-Acc who steal-PAST \\ 'Who stole the money?' (Kim 1988: 158)}

It remains an open and perhaps unanswerable question as to how much 'leaking' a particular position is allowed and can yet still be characterised as a focus position. For the current discussion, we rely on claims in the literature for a certain dedicated position, while being aware of critical counterexamples (Drubig and Schaffar 2001; King 2004; Yip 2004). These counterexamples can lead us to reject a claim of a language having a dedicated focus position. Eastern Armenian, for example, has been characterised as requiring the focus to be adjacent to the auxiliary, much like an IBV focus position (Tamrazian 1991). However, new information can occur in non-IBV position, negation can intervene between focus and the auxiliary, and indefinite nominals need to be adjacent to the auxiliary too, like in Turkish (Comrie 1984). It seems that, rather than having a dedicated focus position, Eastern Armenian has a mobile auxiliary clitic that marks focus (Megerdoomian 2011), and thus should not be considered as a language with an IBV focus position.

What we thus mean when referring to a focus position is a position that various tests show to be in an unambiguous relation with focus, while leaving room for minor consistent exceptions. An initial position is a position where it is clear that other elements (typically or exclusively) follow the focused element, and a final position is one where other elements precede the focused element, excluding possible hanging topics in the left periphery that are outside the core clause ('fish, I like cod') and afterthoughts or marginalised elements in the right periphery ('I like it, the fish that is'). For example, when an SVO language expresses object focus by the order OSV, this shows that focus is not expressed in its canonical position and also that the focus position is not immediately before the verb, but rather it is initial.

A second issue concerns the structure of a sentence containing term focus as a biclausal cleft structure or a monoclausal focus strategy. The biclausal cleft consists of a predicative nominal ('it is the stick') and a relative clause ('that the children broke'), which together result in a focus reading:

\section{(21) Lubukusu}

Lw-á-bá lú-u-saala ní-lwó bá-bá-ana bá-a-lu-funa.
11sm-PST-be AUG-11-stick
'It was the stick that the children broke.' (Diercks 2011: 708)

This construction is known to frequently develop into a monoclausal focus marking strategy (Heine and Reh 1984; Harris and Campbell 1995), where in 
various steps the clauses undergo fusion and often one of the morphemes in the original cleft, such as the copula or the relative marker, becomes a morphological focus marker:

$$
\begin{array}{ll}
\text { [copula NP] - [relative clause }] & >\left[\mathrm{NP}_{\text {focus }} \text { verb }\right] \\
\text { It is Maud - (the person/one) who made pancakes } & >\text { MAUD (FOC) made pancakes }
\end{array}
$$

This is presumably what has happened in Kikuyu, where the copula in an original cleft ('it is water') has grammaticalised to become a focus marker in a simple clause:

(23) Kikuyu

a. Abdul ne morutani.

Abdul cop teacher

'Abdul is a teacher.'

b. Ne mae abdul a-ra-nuy-ire.

COP/FOC 6.water Abdul SM1-T-drink-PERF

'Abdul drank WATER.' (Schwarz 2007: 140,141, adapted)

However, it is often difficult to establish where a construction in a given language is in the grammaticalisation process. Grammaticalisation proceeds via small changes, such as the ones in (24). As they may show conflicting properties, some being evidence of biclausality and others of monoclausality, it is not always possible to establish whether the underlying structure is a cleft or a simple focus construction.

(24) Changes biclausal > monoclausal (Harris and Campbell 1995: 166, 167)

- changing the case of the focused constituent

- changing the form of the focus marker to lookless like the copula or relativiser

- dropping the copula or relativiser altogether

- ceasing to use a special verb form

- (re)introducing agreement according to monoclausal structure

- $\quad$ reordering of constituents

This is relevant to our research, as it is concerned with the expression of focus in dedicated positions within the clause. As such, biclausal clefts are different from monoclausal focus constructions and therefore should not to be taken into account in our comparative overview. We have taken this into consideration when looking at the various focus strategies in our sample, but again have to rely in part on what the authors describe. Yucatec Maya is an example of a language for which inclusion in the sample is debatable. Term focus in this VSO language is 
expressed in the position immediately before the verb, as shown in the OVS order in (25). When the agent is focused, a special form of the verb needs to be used, as seen in the difference between the neutral example in (25b) and subject focus in $(25 c)$.

(25) Yucatec Maya

a. Òon hàant-ah Pèedróoh.

avocado PFV=PMA.3 eat:TRR-CMPL(PMB.3.SG) Pedro

'It was (an) avocado that Pedro ate.'

b. $T=u$ hàant-ah òn Pèedróoh.

PFV=PMA.3 eat:TRR-CMPL(PMB.3.sG) avocado Pedro

'Pedro ate avocado.'

c. Pèédróoh hàant òon.

Pedro eat:TRR(SUBJ)(PMB.3.sG) avocado

'It was Pedro who ate (an) avocado.' (Verhoeven and Skopeteas 2015: 3,4)

Yucatec Maya could thus be seen as a language with IBV focus position and morphological marking on the verb (i.e. in the same category as the Bantu languages Mbuun and Kikongo, discussed below). Indeed, a monoclausal analysis has been proposed by Gutiérrez Bravo and Monforte (2009) and Verhoeven and Skopeteas (2015). However, it has also been shown that the verbal morphology is present not just in the case of subject focus, but in extraction in general (Stiebels 2006). Furthermore, since nominal predication is not marked (i.e. no copula is required), the focus construction can also be analysed as a bare cleft, as argued for by Bricker (1979), Bohnemeyer (2002, 2008), Tonhauser (2003), and Vapnarsky (2013). Since the status of the construction as monoclausal or biclausal is unclear, we have not included it in our study.

Having discussed the definitional and methodological preliminaries to our study, in the next section we turn to the results of our research into the typology of focus-expressing strategies in morphology and word order, and especially the combination of the two.

\section{The focus-marking landscape}

As described in Section 2, we propose a typology of focus marking defined along two parameters: syntactic position and morphological marking. The current section presents the results of our cross-linguistic study of topological and morphological focus marking. 
Table 4: Distribution of languages with simultaneous syntactic and morphological marking of focus.

\begin{tabular}{|c|c|c|c|c|}
\hline Morphology & Initial & IBV & IAV & Final \\
\hline On term & $\begin{array}{l}\text { Gungbe, Jamaican } \\
\text { Creole, Kikuyu, } \\
\text { Kituba, Lingala }\end{array}$ & $\begin{array}{l}\text { Hindi, } \\
\text { Selayar }\end{array}$ & Aghem, Noni, Tunen & Ngizim \\
\hline On verb & $\begin{array}{l}\text { Gâbunke Fula, } \\
\text { Karitiâna, Sereer }\end{array}$ & $\begin{array}{l}\text { Mbuun, } \\
\text { Kikongo }\end{array}$ & $\begin{array}{l}\text { Bemba, Haya, } \\
\text { Makhuwa, Matengo, } \\
\text { Naki, Podoko, Zulu }\end{array}$ & $\begin{array}{l}\text { Kinyarwanda, } \\
\text { Kirundi }\end{array}$ \\
\hline
\end{tabular}

In Section 2 we established four settings for our topology parameter: initial, immediately before the verb (IBV), immediately after the verb (IAV) and final. With four possible structural positions, each of which is defined binarily for marking on the term itself or marking on the verb, the findings of our study are presented in Table 4. As can be seen in the table, there are eight possible combinations for morphological and topological marking of focus, all of which are encountered. Bantoid/Bantu languages in the table are in italics. ${ }^{11}$

An examination of the table reveals that the heart of the conjoint/disjoint alternation is found in the combination of an IAV focus position and morphological marking on the verb. Other Bantu languages also use one of these values, combining IAV with morphological marking on the term, or combining marking on the verb with a final position. The post-verbal (IAV and final) positions seem to be preferred in Bantu. With respect to the non-Bantu languages in our sample, they are distributed across five of the eight possible combinations, generally preferring pre-verbal positions.

The subsequent sections of this chapter illustrate the focus-marking strategies employed by the non-Bantu languages and the Bantu languages of our sample, fitting these within the wider cross-linguistic typology. Observations resulting from this exploration will constitute conclusions presented in Section 5.

\subsection{Non-Bantu languages: the wider typology}

As Table 5 shows, the non-Bantu languages of our sample occupy five of the cells in the table: Focus can be marked topologically in every position (initial/final,

11 We group Aghem (Grassfields Bantu), Naki and Noni (non-Bantu Bantoid) together with the Bantu languages of our sample in a (strictly speaking) Bantoid/Bantu group, although in what follows we will refer to the group simply as Bantu. 
Table 5: The non-Bantu languages.

\begin{tabular}{|c|c|c|c|c|}
\hline Morphology & Initial & IBV & IAV & Final \\
\hline On term & Gungbe, Jamaican Creole & Hindi, Selayar & & Ngizim \\
\hline On verb & Gâbunke Fula, Karitiâna, Sereer & & Podoko & \\
\hline
\end{tabular}

IBV/IAV) but there are restrictions on the morphological marking, which appears on the term only when the focus position is not IAV, and on the verb when the focus position is initial or IAV. In other words, it is only the initial focus position in which both morphological marking on the term and on the verb are found, while the three other positions go with one or the other of the morphological marking options.

The first combination of values is illustrated by Gungbe (Aboh 2007) and Jamaican Creole (Durrleman-Tame 2008), which employ the clause-initial position and morphologically mark focus on the term. Gungbe (Kwa, Benin) is an SVO language in which focused constituents are positioned in the sentence-initial position. ${ }^{12}$ Thus in the examples in (26) below, the focused nominal expressions Sèsinú and Àsíâbá are placed clause-initially. These nominal elements are also obligatorily followed by the morphological focus marker wè.

(26) Gungbe

a. Sèsínú wè dà Àsíàbá.

Sessinou FOC marry Asiaba

'SESSINIOU married Asiaba.'

b. Àsíàbá wè Sèsínú dà.

Asiaba Foc Sessinou marry

'Sessinou married ASIABA.' (Aboh 2007: 289)

An initial focus position is found in a number of Atlantic languages (Robert 2010), represented by Gâbunke Fula (Atlantic, Senegal) and Sereer (Atlantic, Senegal) in the table, as well as in Karitiâna (Tupi, Brazil), all of which exhibit SVO constituent order. However, in these languages the morphological marking of focus is located on the verb. We illustrate this for Karitianna, where the object-focus prefix $t i$ - is attached to the verb to mark focus on the object. At the same time, the focused object occurs in a non-canonical initial position, as seen by the subject intervening between the focused object and the verb (resulting in OSV order):

12 Disregarding possibly preceding topics, as mentioned in Section 3. 
(27)

Karitiâna

a. Mō̄āāmōn a-ti-hī̄āe ?

what 2sG.ABS-OF-smell

'What did you smell?'

b. Eposi:d inn ti-hīrạ -t.

flower 1SG oF-smell-NFUT

'I smelled a flower.'

$$
\begin{aligned}
& \text { Mõ̃̃ãmõn sopãm ti-m?a-tz̃ña-t } \quad(h \tilde{t}) ? \\
& \text { what/who Sopãm oF-make-PROG-NFUT Q } \\
& \text { 'What is Sopãm making?' (Everett 2006: 325, via Van Valin 2009) }
\end{aligned}
$$

Hindi and Selayar (Austronesian, Indonesia) in Table 5 are languages which show an IBV focus position and also employ a morphological strategy for the expression of focus (see Butt and King (1996), Kidwai (1999) for this in Hindi and Finer (1994) and Frascarelli (1999) for this in Selayar). Combining IBV focus position with a focus marker on the term is illustrated here with data from Hindi.

While Hindi has a dominant SOV order, a sentence with a subject, verb and object can have all six possible constituent orders (Butt and King 1996). When there is more than one preverbal element, the first is typically interpreted as the topic and the immediately preverbal one as the focused constituent. IBV in Hindi is illustrated in (29), where the subject Raam is in focus:

(29) Hindi

Kitaab Raam laayegaa, (siitaa nahii).

book Ram bring.FuT Sita not

'RAM will bring the book, not Sita.' (Kidwai 1999: 228)

Hindi also makes use of the morphological focus marker hii, which marks narrow focus (Kidwai 1999; in Sharma 2003 hii marks exclusive contrastive focus) and can follow the focused constituent in the IBV position:

(30) Hindi

Kitaab Raam-hii laayegaa (siitaa nahii).

book Ram-Foc bring.FuT Sita not

'RAM will bring the book, not Sita.' (Kidwai 1999: 223, adapted)

The focus marker hii, however, can be used independently of the IBV focus position as can be seen in (31) and (32), where the focused subjects appear in their canonical position: 
(31) Hindi

$$
\begin{array}{llll}
\text { Maya=ne hii anu=ko kitaab dii. } & \\
\text { Maya=ERG FOC anu=DAT book.NOM } & \text { give.PERF.F.SG } \\
\text { 'MAYA only gave Anu a book.' (Sharma 2003: 63) }
\end{array}
$$

(32) Hindi

$$
\begin{aligned}
& \text { Raam-hii kitaab laayegaa, (siitaa nahii). } \\
& \text { Ram-Foc book bring.FUT Sita not } \\
& \text { 'RAM will bring the book, not Sita.' (Kidwai 1999: 228, adapted) }
\end{aligned}
$$

The two strategies (topological and morphological focus marking) can thus be used simultaneously or independently in Hindi. In our typology we are concerned with co-occurring syntactic and morphological focus-marking strategies, which seems to be the case in (30), where the focused subject Raam is not in its canonical position and is followed by hii. The independence of syntactic and morphological marking is further discussed in our conclusion in Section 5.

The use of the IAV position with focus marked on the verb is found in Podoko (Chadic, Cameroon). Podoko has a basic VSO word order with possible focused elements intervening between the verb and the subject (Jarvis 1991). For example, in (33b) a dzangə 'on the mountain' is placed immediately following the verb, which is preceded by $a$. In contrast, in (33a) no expression intervenes between the verb and the subject, which is now marked with a high tone údzara 'child' (or in the case of some pronouns it will carry the prefix $m$-). Also, the verb is not preceded by $a .^{13}$

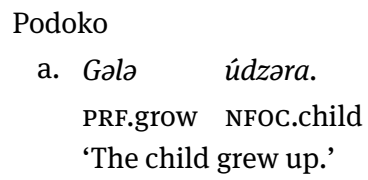

$\begin{array}{lllll}\text { b. A gála } & a ́ & \text { dzanga udzara. } \\ \text { FOC } & \text { PRF.grow } & \text { on mountain child }\end{array}$ 'It was on the mountain that the child grew up.' (Jarvis 1991: 216, adapted glosses)

Our study identified one language which employs the sentence final position for topological marking of focus and morphological marking on the term. Ngizim (West Chadic, Nigeria) is an SVO language which employs an inversion construction, resulting in a focused subject. In these constructions, the basic 'neutral' word order is deviated from and the focused subject appears in the final position

13 See Jarvis (1991) for more information on the additional role of aspect in Podoko. 
preceded by a focus particle $n$ (Zimmermann 2011). This is illustrated in (34) with a question-answer pair where both the wh-word and the term in focus are realised in a final position.

(34) Ngizim
a. dauraw Nyabe $n$ tai?
call.PFV Nyabe Foc who
'Who called Nyabe?'
b. dauraw Nyabe $n$ Anja.
call.PFv Nyabe Foc Anja
'Anja called Nyabe.'
c. *dauraw Nyabe Anja.
call.PFV Nyabe Anja
Intended: 'Anja called Nyabe.' (Grubic 2010: 21-22)

In sum, the non-Bantu languages of our sample predominantly mark focus morphologically on the term, and topologically in initial, IBV or final position. Ngizim is the only language in our sample which combines focus marking on the term with a final focus position, while Podoko is the only non-Bantu language in our sample which combines the IAV position with term focus morphologically marked on the verb. In contrast, several languages employ an initial focus position, and a combination of both marking on the verb and on the term. As we will show in the next section, the typological space occupied by the Bantu languages of our sample is in largely complementary distribution with the space occupied by the non-Bantu languages.

\subsection{The Bantu languages}

As outlined at the beginning of this section, Bantu languages occupy five of the cells in our table. Kikuyu, Kituba and Lingala occupy the initial/on term cell; Mbuun and Kikongo occupy the IBV/on verb cell; and the closely related Kirundi and Kinyarwanda occupy the final/on verb cell. The remainder of the Bantu languages in our sample are concentrated in the IAV position. The IAV/on term languages are Aghem, Noni and Tunen, while the languages which employ the IAV position and mark focus morphologically on the verb are Bemba, Haya, Makhuwa, Matengo, Naki and Zulu. This is summarised in Table 6.

The first combination of parameters we discuss with respect to Bantu languages is focus marked on the term in the initial position. Kituba and Lingala 
Table 6: Locating the Bantu languages within the broader typology.

\begin{tabular}{|c|c|c|c|c|}
\hline Morphology & Initial & IBV & IAV & Final \\
\hline On term & $\begin{array}{l}\text { Kikuyu, Kituba, } \\
\text { Lingala }\end{array}$ & & Aghem, Noni, Tunen & \\
\hline On verb & & $\begin{array}{l}\text { Mbuun, } \\
\text { Kikongo }\end{array}$ & $\begin{array}{l}\text { Bemba, Haya, Makhuwa, } \\
\text { Matengo, Naki, Zulu }\end{array}$ & $\begin{array}{l}\text { Kinyarwanda, } \\
\text { Kirundi }\end{array}$ \\
\hline
\end{tabular}

(Van der Wal and Maniacky 2015) as well as Kikuyu (Schwarz 2007; Morimoto this volume) employ this strategy. In Kikuyu (E51, Kenya), both question words and answers need to occupy the initial position and be preceded by the marker ne:

(35) Kikuyu
a. N-oo o-ðom-ay-era mwana ißuku?
FOC-who 1SM-read-HAB-APPL 1.child 5.book
'Who (usually) reads a/the book to the child?'
b. Ne Abdule o-ðom-ay-era mwana ißuku.
FOC 1.Abdul 1SM-read-HAB-APPL 1.child 5.book
'It is Abdul who reads a/the book to the child.' (Schwarz 2003: 57)

A further combination of parameter settings is to have a dedicated focus position immediately before the verb (IBV) but indicate focus morphologically on the verb rather than the term itself. This is the case in Mbuun (Bantu B87, DRC) and Kikongo (H16, DRC). Bostoen and Mundeke (2012) show that in Mbuun the subject marker in class 1 varies depending on which element in the sentence is focused, as given in Table 7. This can be seen as a morphological marking of focus on the verb, even if it differs from the conjoint/disjoint marking as found in other Bantu languages, and also from non-Bantu focus morphology on the verb, where the morphology seems attached to TAM morphology. De Kind (2014) shows the same pattern for varieties of Kikongo.

Bostoen and Mundeke (2012) also show that focused elements are placed in the position immediately preceding the verb, as shown in (36a) and (36b): the

Table 7: Class 1 subject markers in Mbuun.

\begin{tabular}{lll}
\hline & Past/perfect & Other tenses \\
\hline No argument focus & ká- & á- \\
Object focus & ká- & ká- \\
Non-object focus & á- & á- \\
\hline
\end{tabular}


basic word order is SVO, object focus SOV, and subject focus OSV. An exception is adjunct focus, which can be expressed in-situ (usually with SVO ordering).

(36) Mbuun
a. Mpfúm ná ká-wó-ból? SOV president who 1SM-PST-hit
'Who did the president hit?'
b. Mpfúm ná á-wó-ból? OSV president who 1SF.SM-PST-hit?
'Who hit the president?'
c. Ampfúm á-ker-loon búl. president 1SF.SM-FUT-repair 14.country
'The president will rebuild the country.'
d. Bâná ká-ker-bú-loonne?
2.who 1SM-FUT-14OM-repair.APPL
'For whom will he rebuild it?'
e. Ámpúr ká-ker-bú-loonne.
2.poor 1SM-FUT-140M-repair.APPL
'He will rebuild it for the poor.'
(Bostoen and Mundeke 2012: 146, 147, adapted glosses)

Moving to the postverbal domain, Bantu languages that have an IAV focus position can morphologically mark the focus on either the term or the verb. The former combination is found in Aghem (Watters 1979; Hyman and Watters 1984; Hyman and Polinsky 2009), Noni (Hyman 1981; Kalinowski and Good 2014) and Tunen (Mous 1997). Aghem (Grassfields Bantu, Cameroon) has a dominant SVO order (37a). Despite this, variable constituent orders can be employed to convey considerations of information structure. Focus expressions and wh-words invariably appear in the IAV position. In fact, it was Aghem focus that was first analysed in detail as having an IAV focus position by Watters (1979). In (37b) the noun phrase tíbvú tìbìghà 'two dogs' appears in the IAV position resulting in a focus interpretation of the subject expression. This can also be seen in (37c), where $n \dot{\varepsilon}$ 'today' appears in the IAV position and is focused. The focused term may be an argument, e.g. a subject (37b), or an adjunct (37c).

(37) Aghem
a. Tí-bví tì-bìghà $m \hat{\jmath} \quad z \grave{z} \quad k \hat{z}-b \hat{\varepsilon} \quad{ }^{\downarrow} n \varepsilon$. dogs two PAST1 eat DET-fufu today
'The two dogs ate fufu today.' 


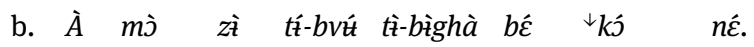
ES PAST1 eat dogs two fufu DET.oBL today

'The two Dogs ate fufu today.'

c. Tí-bvú tì-bìghà $m \hat{\jmath} \quad z \grave{t} \quad n \hat{\varepsilon} \quad{ }^{\downarrow} b \hat{\varepsilon} \quad{ }^{\downarrow} k \hat{\jmath}$. dogs two PAST1 eat today fufu DET.OBL

'The two dogs ate fufu ToDAy.' (Hyman and Polinsky 2009: 206/7)

The Aghem IAV position is associated with identificational focus. Wh-words also appear in the IAV position (38).

(38) Aghem

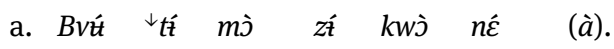 dogs DET PAST2 eat what today QM 'What did the dogs eat today?'

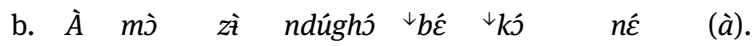 ES PAST1 eat who fufu DET.OBL today QM 'Who ate the fufu today?'
c. Tí-bví tì-bìghà $m \hat{\jmath}$ zì zín bé ${ }^{\downarrow} k j \quad$ (á). dogs two PAST1 eat when fufu DET.OBL QM 'When did the two dogs eat the fufu?' (Hyman and Polinsky 2009: 207/8)

Noun phrases in Aghem also exhibit an alternation in form according to their focal status, differing between so-called A and B forms such as tábvú 'dogs' (A form) and bvút ${ }^{\downarrow}$ tó 'dogs' (B form) or álím 'yams' (A form) and lím ghś 'yams' (B form). The A form is used when the noun is in focus or is expectedly out of focus (Watters 1979: 56), e.g. when it is an object and appears in the IAV position. In contrast, the $B$ form is used when the noun is unexpectedly out of focus. The noun for 'fufu', for example, appears in the A form as kítb́ (comprised of the prefix $k \hat{t}$ - and the nominal root $b \hat{\varepsilon}$ ) and when it is the object of an affirmative sentence (39a). However, it appears in the B form as b $\hat{\varepsilon}^{\downarrow} k o ́$ (with the root $b \dot{\varepsilon}$ and the determiner $k \hat{s}$ ) when it is not focused, e.g. when it appears after a focused IAV element (39b) or in the IBV position (39c). ${ }^{14}$

(39) Aghem
$\begin{array}{llllll}\text { a. } & \grave{M} & m \hat{\jmath} & z \grave{z} & k \hat{z}-b \hat{\varepsilon} & { }^{\downarrow} n \hat{\varepsilon} . \\ & \text { I } & \text { PAST }_{1} & \text { ate } & \text { fufu today }\end{array}$
'I ate fufu today.'

14 In (39c) $b \hat{\varepsilon}^{\downarrow} k \hat{j}$ appears as $b \hat{\varepsilon}^{\downarrow} k \hat{t}$ due to a phonological rule which results in the allomorphic realization of $C \dot{z}$ and $C$. This does not relate to focus in the same way as the distinction between $k \hat{z} b \dot{\varepsilon} / b \hat{\varepsilon}^{\downarrow} k \dot{s}$. 
b. $\quad \grave{M} m \hat{\jmath} \quad z \grave{z} \quad{ }^{\downarrow} n \hat{\varepsilon} \quad b \hat{\varepsilon}-k \dot{j}$.

I PAST $_{1}$ ate today fufu

'I ate fufu TODAY.' (Hyman 1979: 56, 59)

c. $\grave{O} \quad m \grave{j} \quad b \dot{\varepsilon} \quad{ }^{\downarrow} k \hat{z} \quad z \grave{z} \quad n \hat{\varepsilon}$.

SM PAST1 fufu DET eat today

'He ate fufu TODAY.' (Hyman 2010: 101, adapted)

The $B$ form is also used in non-IAV post-verbal position (40a) (where the use of the A form would render the sentence ungrammatical) and after the focal auxiliary maa (40b), which renders focus on the truth value rather than the postverbal element. The $\mathrm{B}$ form is also required in relative clauses and with negatives and imperatives. ${ }^{15}$

(40) Aghem

'He ate fufu ToDAY.'

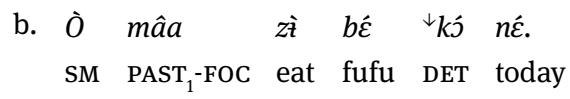

'He did eat fufu today.' (Hyman 2010: 101/2, adapted)

In Aghem, a matrix clause cannot end in a bare verb. Rather, intransitive verbs and transitive verbs that appear without a postverbal object obligatorily have their IAV position filled. This results in an 'in situ' focus reading of the verb which has been analysed in similar terms as the conjoint/disjoint alternation (Hyman and Watters 1984; Creissels 1996; Güldemann 2003; Buell 2006). The obligatory placement of the particle nò after verbs without postverbal objects can be seen in (41).

(41) Aghem
a. Ò mò bvìu ${ }^{*}$ (nò).
3SG PAST1 fall FM
'He fell.'
b. $\grave{O} \quad m \grave{j} \quad z \grave{\imath} \quad *(n \hat{o})$.
3SG PAST1 eat FM
'He ate (it).'

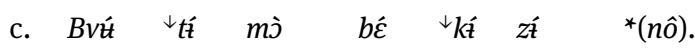
dogs DET PAST2 fufu DET eat FM

'The dogs ATE the fufu.' (Hyman and Polinsky 2009: 207)

15 The full picture is actually slightly more complicated than we present it here, and a comprehensive analysis of the facts remains outstanding. Cf. Hyman $(1979,1985,2010)$ and Watters (1979) for discussion. 
Like Aghem, Tunen marks focus in the IAV position. However, while Aghem is a basic SVO language, word-order in Tunen is more complex and it is one of the few Bantu languages in which the direct object typically precedes the verb (42a). When the object is (contrastively) focused, it follows the verb, and is in addition marked with a contrastive particle $a$ (42b).

(42) Tunen
a. Àná mòné índì.
3s:PST money give
'S/he gave money.'
b. Àná índì á mòné.
3s:PST give PRT money
'S/he gave MONEY.' (Mous 1997: 126)

Our small typology thus shows that IAV focus is found with both SVO languages (Aghem, Noni, Bemba, Haya, Makhuwa, Matengo, Naki, Zulu) and SOV languages (Tunen). Conversely, the two Bantu languages with IBV focus - Mbuun and Kikongo - are otherwise SVO languages. There is thus no absolute correlation in our sample between basic word-order and focus position with respect to the verb (IBV/IAV), in contrast to wider cross-linguistic trends (cf. Herring 1990).

The other option for languages with an IAV focus position is to morphologically mark focus on the verb. The one non-Bantu language identified in our study which belongs to this system is Podoko, but the majority of the languages belonging to this type are Bantu languages, since this is the combination as instantiated in the canonical conjoint/disjoint system. Languages in our sample which fall into this category include Bemba (M42), Haya (E24), Matengo (N13), Makhuwa (P31), Naki and Zulu (S42). For example, Makhuwa makes use of an IAV position which is directly and unambiguously related to (exclusive) focus. This was illustrated in Section 3, where three tests were applied to both the topology and the morphology marking focus in Makhuwa. Naki, a SVO Bantoid language of Cameroon, also employs the IAV position for the marking of verbal focus. In some tenses this construction in Naki is also associated with a special tone marking. This can be seen in comparison of the examples (43) below, where the verb in example (43a) exhibits a High-Mid tone pattern while example (43b) shows High-High. ${ }^{16}$

16 Whilst Naki is not considered to have a conjoint/disjoint alternation in the true sense, Good (2010: 18) notes that the distinction between confluentive and disfluentive verb forms found in Naki (as exemplified in 43) is "clearly reminiscent of the opposition between conjoint and disjoint verb forms found in many (Narrow) Bantu languages...”. 
(43) Naki
a. Kúm ájē ūnā wà
Kum eat.PST 5.fufu 5.the
'Kum ate the fufu.'
b. Ūnā wà ájé Kúm
5.fufu 5.the eat.PST.DSF Kum
'KUM ate the fufu.' (Good 2010: 47)

Finally, we identified only two Bantu languages which make use of the final position to mark focus, with focus morphologically marked on the verb. These are Kirundi and Kinyarwanda, two closely related languages spoken in Burundi and Rwanda respectively. It appears that these two languages reflect a minor variant of sorts, showing a geographically restricted distribution of the conjoint/disjoint form found in contiguous countries.

In Kirundi (D62), the disjoint form conveys focus on the verb (Sabimana 1986; Ndayiragije 1999; Nshemezimana \& Bostoen this volume), while use of the conjoint verb form results in focus on the element in clause-final position. As such, we consider Kirundi to be an example of a language which employs a sentencefinal dedicated focus position (but see Nshemezimana and Bostoen this volume for a different analysis). The use of this position can be seen in the examples below where (44a) shows the conjoint form resulting in clause-final focus while (44b) shows the disjoint form, resulting in focus on the verb.

(44) Kirundi
a. CJ Mariya a-Ø-kund-a a-b-âna.
Mary 1SM-PRES-like-ASP AUG-2-child
'Mary likes CHILDREN.'
b. DJ Mariya a-Ø-ra-kûnd-a a-b-âna.
Mary 1SM-PRES-DJ-like-ASP AUG-2-child
'Mary LIKES children.' (Sabimana 1986: 237)

An attempt at using the disjoint form renders the sentence ungrammatical when some other NP in the clause is focused (cf. (45a) and (45b)) where the conjoint form must be used instead (45c).

(45) Kirundi
a. DJ ${ }^{\star} H$-ă-ra-sinziriye Mudúga.
16SM-F.PAST-DJ-sleep Muduga
'It is Muduga who slept.' 
b. DJ *Ha-Ø-ra-kund-a a-b-âna Mariyá. 16SM-PRES-DJ-like-ASP AUG-2-child Mary 'It is Mary who likes children.'

c. CJ Ha-Ø-kund-a a-b-âna Mariyá. 16SM-PRES-like-ASP AUG-2-child Mary

'It is Mary who likes children.' (Sabimana 1986: 62, 238)

The conjoint form is used in question-answer pairs for both objects and adverbs (46).

(46) Kirundi (Nshemezimana and Bostoen 2013)

a. CJ A-ba-na ba-nyu ba-kund-a i-bi-igwa ki? AUG-2-child POSS-2PL 2SM-like-FV AUG-8-subject which 'Which subjects do your children like?'

b. CJ A-ba-iísuumbur-ye ba-Ø-kuund-a i-bi-háryyri u-wu-ki-ri AUG-2-be.big-PFV 2SM-CJ-like-FV AUG-8-maths AUG-1-PERS-be mu-tó na wé a-kuund-a i-bi-gi-an-ye 1-young and 3sg 1SM- $\varnothing$-like-FV AUG-8-go-ASS-PFV n' i-n-domé. with AUG-10-literature 'The older ones like maths, but the youngest like subjects related to literature.'

Where Kirundi is special as compared to other conjoint/disjoint languages is its final focus position. This can be seen in subject focus (47), which shows VerbGoal-Patient-Subject order, and in double object constructions, where the relative order of the two objects is determined by considerations of focus, as in (48).

(47) Kirundi

H-a:-zan-i-ye a-b-âna u-mu-p̌ra Maríya.

16SM-R.PAST-bring-APPL-ASP AUG-2-child AUG-3-ball Mary

'It is Mary who brought a ball for the children.' (Sabimana 1986: 191)

(48) Kirundi

a. Mudúga, y-a-hâye a-b-âna i-gi-tabo.

Muduga 1SM-F.PAST-give AUG-2-child AUG-7-book

'Muduga, he gave the children A воок.'

b. Mudúga, y-a-hâye i-gi-tabo a-b-âna.

Muduga 1SM-F.PAST-give AUG-7-book AUG-2-child

'Muduga, he gave THE CHILDREN a book.' (Sabimana 1986: 91) 
To summarise, this section has provided an overview of the findings of our study in relation to both the Bantu and non-Bantu languages. Employing the four syntactic parameters each defined for morphological marking on the term or on the verb, we have identified eight possible combinations of focus marking. Our study has shown that all cells in the table are filled, i.e. that all combinations of parameter settings are encountered. The non-Bantu languages occupy five of the cells of our table: morphological marking on the term plus initial, IBV or final position, and morphological marking on the verb in conjunction with an initial or an IAV focus position. The Bantu languages occupy five spaces identified by morphological marking on the verb with IBV, IAV or final position, and morphological marking of the term with initial or IAV position all attested. The next section identifies and discusses this distribution in more detail, and offers some conclusions that can be obtained from this observation and related findings.

\section{Conclusions}

The main contribution of our chapter has been to show how Bantu conjoint/disjoint systems relate to the wider typology of focus marking. We have restricted our attention to the interaction of syntactic and morphological marking of term focus, disregarding for the time being prosodic marking of focus and the expression of predicate-centred focus. We concentrated on languages with constructions which simultaneously employ syntactic and morphological means to mark focus and used a sample of 25 languages where these constructions can be found, including sixteen Bantu and nine non-Bantu languages. Adopting two dimensions of variation - syntactic focus position and marking on the term vs. marking on the verb - we created a typological space of eight logically possible value combinations for the two dimensions, which provided the basis for our classification, shown here again in Table 8.

The main findings of our study are as follows. Firstly, even based on our relatively small sample, we show that the entire typological space is exploited, and so that each possible value combination is attested by at least one language. Our typology thus models a cross-linguistically well-populated aspect of variation in focus marking. Secondly, the distribution of Bantu languages and non-Bantu languages in our sample is largely complementary, with only two cells 'overlapping'. Thirdly, the distribution of the Bantu languages in general, and of those Bantu languages with conjoint/disjoint systems, cannot be described by one dimension or a unique value combination.

The complementarity of Bantu and non-Bantu languages in our sample can be seen to result from two central aspects of Bantu focus marking: First, Bantu 
Table 8: Distribution of 25 languages with simultaneous syntactic and morphological marking of focus.

\begin{tabular}{|c|c|c|c|c|}
\hline${ }_{\text {Morphology }}^{\text {Topology }}$ & Initial & IBV & IAV & Final \\
\hline On term & $\begin{array}{l}\text { Gungbe, Jamaican } \\
\text { Creole, Kikuyu, } \\
\text { Kituba, Lingala }\end{array}$ & $\begin{array}{l}\text { Hindi, } \\
\text { Selayar }\end{array}$ & $\begin{array}{l}\text { Aghem, Noni, } \\
\text { Tunen }\end{array}$ & Ngizim \\
\hline On verb & $\begin{array}{l}\text { Gâbunke Fula, } \\
\text { Karitiâna, Sereer }\end{array}$ & $\begin{array}{l}\text { Mbuun, } \\
\text { Kikongo }\end{array}$ & $\begin{array}{l}\text { Bemba, Haya, } \\
\text { Makhuwa, Matengo, } \\
\text { Naki, Zulu, Podoko }\end{array}$ & $\begin{array}{l}\text { Kinyarwanda, } \\
\text { Kirundi }\end{array}$ \\
\hline
\end{tabular}

languages show a general preference for focus to be post-verbal, whether in the IAV or final position. Second, morphological focus marking on the verb seems to be rare outside Bantu (although see the Atlantic languages). This may be due to the restriction that morphological marking of focus on the verb appears not to occur in languages which are generally dependent-marking (Van der Wal 2014), and the general head-marking nature of Bantu languages. This in turn triggers the question of whether a linguistic profile of rich verbal morphology is a precondition across the board for marking term focus on the verb (see also Kalinowski and Good 2014). In addition, one may ask whether areal influences play a role, for example in the Bantoid languages of the north-west, where Naki, Noni and Aghem all show the IAV effect (Good 2010).

With respect to the internal variation of focus marking in Bantu, it is interesting to note that the cases of an initial focus position with morphological marking on the term are all (relatively) transparent and recently derived from a cleft construction. The various morphological markings on the verb, in contrast, are all much older and (as a result) much less transparent. Further observations are the independence of IAV and conjoint/disjoint, as witnessed by the languages from the northwest of the Bantu area (only IAV) and Kirundi/Kinyarwanda (only conjoint/disjoint), as well as the presence of an IAV focus position in languages with basic SVO order such as Aghem or Bemba (as expected) and (less expectedly) in Tunen, which has SOV.

There are aspects of conjoint/disjoint systems, and focus marking more widely, which are not addressed by our study, inclusion of which would almost certainly make the situation more complex than can be seen from our findings. Firstly, with only 25 languages, our sample is small. The overall picture would be likely to change if more languages were included, either by identifying more languages with the relevant morphosyntactic profile (Southern Quechua, cf. Muysken 1995, and Yoruba, cf. Bisang and Sonaiya 2000, being possible candidates), or by 
inclusion of a wider range of constructions, for example constructions with only one strategy of focus marking, e.g. only a morphological marker on the term or only marking on the verb (see again Smit 2010; Kalinowski and Good 2014). An inclusion of prosodic marking and verb focus would also further diversify the picture.

In addition, even for the constructions which we did include, there remain aspects which have not been taken into account, in part because relevant information is often hard to find. Two main issues here are the exact interpretation of the focus, and optionality of focus marking strategies. With respect to the first, it would be interesting to see whether there is a consistent correlation between certain topological and morphological marking (and/or combinations thereof) and a certain type or scope of focus. For example, is it the case that an initial position always expresses identificational focus on the term, or that marking on the verb is new information focus? Could it be that the IBV and IAV positions are always underspecified for object and VP focus?

With respect to the second point, our investigation concentrated on languages in which a construction is present which involves the simultaneous use of topological and morphological focus marking. We found, however, that there are languages in which the two strategies may optionally be used together. For example, while Gungbe obligatorily combines the use of a focus marker with a dedicated focus position, in Hindi the two may be used simultaneously or independently of each other. Another relevant example here is Ngizim in which subjects have a special status when it comes to focus - focus on subjects is always 'doubly marked' (Zimmermann 2011: 1167) as opposed to focus on non-subjects. Wethusfind threetypesoflanguages:1)Wherethetwotypesofmarkings havetocooccur, 2) Where either type of marking can occur independently, and 3) Where one marking type is dependent on the presence of the other. ${ }^{17}$ This is a particularly interesting issue with respect to conjoint/disjoint systems as we know that the distinction is often restricted to only a subset of tense-aspect paradigms, and so the question arises whether syntactic marking is independent of the presence of head-marking. For example, in Zulu the conjoint/disjoint distinction is restricted to the present and perfect tenses, where IAV and morphological marking on the verb go hand-in-hand (Buell 2006). But is focus in, for example, the future tense in Zulu - which does not show morphological conjoint/disjoint marking (but see Zeller, Zerbian \& Cook this volume) - still related to the IAV position? Questions such as these all remain as paths for

17 The distribution poses also an interesting question for language change and whether diachronic processes can be found resulting in the building up of double marking and its loss. 
future enquiry. Furthermore, Hartmann and Zimmermann (2004: 217) note that "languages that mark focus by movement sometimes use morphological marking or a change of verbal aspect in addition. Their grammatical systems appear to be somewhat uneconomical with respect to focus marking." This triggers the question of whether either topological or morphological marking can be said to be the 'real' or primary focus marker.

In summary, we established a focus-marking typology based on syntactic position and morphological marking of term focus. Based on our sample of 25 languages we have shown Bantu languages to occupy positions which largely reflect the predominance of verbal marking for term focus and a syntactic IAV position in the language family. We make no claims of exhaustivity. However, we believe we have shown that it is profitable to embed the Bantu conjoint/disjoint systems within the wider typological context of cross-linguistic marking of focus, both from the point of view of comparative Bantu, and from the point of view of crosslinguistic investigations into variation in the expression of information structure.

\section{Abbreviations}

$\begin{array}{llll}\text { A } & \text { augment } & \text { F.PAST } & \text { far past } \\ \text { ABS } & \text { absolutive } & \text { FOC } & \text { focus } \\ \text { ACC } & \text { accusative case } & \text { FUT } & \text { future } \\ \text { APPL } & \text { applicative } & \text { FV } & \text { final vowel } \\ \text { ASP } & \text { aspect } & \text { LAT } & \text { lative } \\ \text { ASS } & \text { associative } & \text { LOC } & \text { locative } \\ \text { B } & \text { person marker } & \text { NFOC } & \text { non-focus } \\ \text { CJ } & \text { conjoint } & \text { NOM } & \text { nominative case } \\ \text { CL } & \text { clitic } & \text { OBL } & \text { oblique } \\ \text { CMPL } & \text { completive } & \text { OF } & \text { object focus } \\ \text { COMP } & \text { complementiser } & \text { OM } & \text { object marker } \\ \text { COP } & \text { copula } & \text { PASS } & \text { passive } \\ \text { DAT } & \text { dative } & \text { PAST1 } & \text { recent past } \\ \text { DET } & \text { determiner } & \text { PAST2 } & \text { distant past } \\ \text { DJ } & \text { disjoint } & \text { PERF } & \text { perfect } \\ \text { DSF } & \text { disfluentive } & \text { PERS } & \text { persistive } \\ \text { DUR } & \text { durative } & \text { PFV } & \text { perfective } \\ \text { EMPH } & \text { emphatic } & \text { PL } & \text { plural } \\ \text { ERG } & \text { ergative } & \text { PMA } & \text { person marker of set 'A' } \\ \text { ES } & \text { expletive subject } & \text { PMB } & \text { person marker of set 'B' } \\ \text { F } & \text { feminine } & \text { POSS } & \text { possessive } \\ \text { FM } & \text { focus marker } & \text { PRES } & \text { present }\end{array}$




$\begin{array}{llll}\text { PRS } & \text { person } & \text { SG } & \text { singular } \\ \text { PRT } & \text { particle } & \text { SUBJ } & \text { subject } \\ \text { PST } & \text { past } & \text { SM } & \text { subject marker } \\ \text { Q } & \text { interrogative } & \text { T } & \text { tense } \\ \text { QM } & \text { question marker } & \text { TAM } & \text { tense-aspect-mood } \\ \text { R.PAST } & \text { recent past } & \text { TRR } & \text { transitivizer } \\ \text { SF } & \text { subject focus } & & \end{array}$

\section{References}

Aboh, Enoch 0. 2004. The morphosyntax of complement-head sequences: Clause structure and word order patterns in Kwa. Oxford: Oxford University Press.

Aboh, Enoch 0. 2007. Focused versus non-focused wh-phrases. In Enoch O. Aboh, Katharina Hartmann \& Malte Zimmermann (eds.), Focus strategies in African languages, 287-314. Berlin: de Gruyter.

Bisang, Walter \& Remi Sonaiya. 2000. Information structuring in Yoruba. Linguistics 38 (1). 169-197.

Bohnemeyer, Jürgen. 2002. The grammar of time reference in Yukatek Maya. Munich: LINCOM.

Bohnemeyer, Jürgen. 2008. Linking without grammatical relations in Yucatec. Alignment, extraction and control. In Johannes Helmbrecht, Yoko Nishina, Y.-M. Shin, Stavros Skopeteas \& Elisabeth Verhoeven (eds.), Form and function in language research, 185-214. Berlin: De Gruyter.

Bostoen, Koen \& Leon Mundeke. 2012. Subject marking, object-verb order and focus in Mbuun (Bantu, B87). Southern African Linguistics and Applied Language Studies 30 (2). 139-154.

Bricker, Victoria R. 1979. Wh-questions, relativization, and clefting in Yucatec Maya. In Laura Martin (ed.), Papers in Mayan linguistics, 109-138. Columbia, MO: Lucas Brothers.

Buell, Leston C. 2006. The Zulu conjoint/disjoint verb alternation: focus or constituency? ZAS Papers in Linguistics 43. 9-30.

Büring, Daniel. 2010. Towards a typology of focus realization. In Malte Zimmermann \& Caronline Féry (eds.), Information structure, 177-205. Oxford: Oxford University Press.

Butt, Miriam \& Tracy Holloway King. 1996. Structural topic and focus without movement. In Miriam Butt \& Tracy Holloway King (eds.), Proceedings of the First LFG Conference. Stanford: CSLI Publications.

Cheng, Lisa Lai-Shen \& Laura J. Downing. 2009. Where's the topic in Zulu? The Linguistic Review 26 (2-3). 207-238.

Comrie, Bernard. 1984. Some formal properties of focus in Modern Eastern Armenian. Annual of Armenian Linguistics 5. 1-21.

Costa, João \& Nancy C. Kula. 2008. Focus at the interface: Evidence from Romance and Bantu. In Cécile De Cat \& Katherine Demuth (eds.), The Bantu-Romance Connection, 293-322. Amsterdam: John Benjamins.

Creissels, Denis. 1996. Conjunctive and disjunctive verb forms in Setswana. South African Journal of African Languages 16 (4). 109-115.

de Kind, Jasper. 2014. Word order in Kikongo (H16): On the origins of a preverbal focus position and the pragmatic neutralization of SOV. Talk given at SynPhonIS, ZAS, Berlin. 
Diercks, Michael. 2011. The morphosyntax of Lubukusu locative inversion and the parameterization of Agree. Lingua 121 (5). 702-720.

Dik, Simon C. 1997. The theory of functional grammar. Berlin, New York: Mouton de Gruyter.

Downing, Laura J. 2013. Issues in the phonology-syntax interface in African languages. In Olanike Ola Orie \& Karen W. Sanders (eds.), Selected Proceedings of the 43rd Annual Conference on African Linguistics, 26-38. Somerville, MA: Cascadilla Proceedings Project.

Downing, Laura J. \& Bernd Pompino-Marshall. 2013. The focus prosody of Chichewa and the Stress-Focus constraint: A response to Samek-Lodovici (2005). Natural Language \& Linguistic Theory 31. 647-681.

Drubig, Hans Bernard \& Wolfram Schaffar. 2001. Focus constructions. In Martin Haspelmath, Ekkehard König, Wulf Oesterreicher \& Wolfgang Raible (eds.), Language typology and language universals, 1079-1104. Berlin: De Gruyter.

Durrleman-Tame, Stephanie. 2008. The syntax of Jamaican Creole. Amsterdam: John Benjamins.

É. Kiss, Katalin. 1998. Identificational focus versus information focus. Language 74 (2). 245-273.

Elders, Stefan. 2006. Conjoint and disjoint in Doyayo: Bantu-like verb forms in an Adamawa language. Talk given at Workshop on focus in African languages, Berlin.

Everett, Caleb. 2006. Patterns in Karitiâna: Perception, articulation and grammar. Houston: Rice University PhD thesis.

Fiedler, Ines. This volume. Conjoint and disjoint verb forms in Gur? Evidence from Yom.

Finer, Daniel L. 1994. On the nature of two A' positions in Selayarese. In Norbert Corver \& Henk van Riemsdijk (eds.), Studies on scrambling, 153-184. Berlin: Mouton de Gruyter.

Foley, William A. 1994. Information structure. In Asher, R. E. (ed.), The encyclopedia of language and linguistics, 1678-1685. Pergamon Press.

Frascarelli, Mara. 1999. Subject, nominative case, agreement and focus. In Lunella Mereu (ed.), Boundaries of morphology and syntax, 195-217. Amsterdam: John Benjamins.

Göksel, Aslı \& A.Sumru Öszoy. 2000. Is there a focus position in Turkish? In Aslı Göksel \& Celia J. Kerslake (eds.), Studies on Turkish and Turkic languages; Proceedings of the ninth International Conference on Turkish Linguistics, 219-228. Wiesbaden: Harrassowitz.

Good, Jeff. 2010. Topic and focus fields in Naki. In Ines Fiedler \& Anne Schwarz (eds.), The expression of information structure. A documentation of its diversity across Africa, 35-68. Amsterdam: John Benjamins.

Grubic, Mira. 2010. Ngizim fieldnotes. In Petrova, S. \& M. Grubic (eds.), Linguistic fieldnotes I: Information structure in African Languages. Working Papers of the SFB 632 (ISIS). 1-76.

Güldemann, Tom. 1996. Verbalmorphologie und Nebenprädikation im Bantu. Bochum: Universitätsverlag Dr. N. Brockmeyer.

Güldemann, Tom. 2003. Present progressive vis-à-vis predication focus in Bantu: A verbal category between semantics and pragmatics. Studies in Language 27 (2). 323-360.

Güldemann, Tom. 2009. Predicate-centered focus types: A sample-based typological study in African languages. Application for project B7 in the CRC 632 Information structure.

Güldemann, Tom, Ines Fiedler, and Yukiko Morimoto. 2014. The verb in the preverbal domain across Bantu: infinitive "fronting" and predicate-centered focus. Paper presented at the Workshop on preverbal domains. ZAS, Berlin.

Gutiérrez Bravo, Rodrigo \& Jorge Monforte. 2009. Focus, agent focus, and relative clauses in Yucatec Maya. In Heriberto Avelino, Jessica Coon \& Elisabeth Norcliffe (eds.), New perspectives in Mayan linguistics. MIT Working Papers in Linguistics. 
Harris, Alice C. \& Lyle Campbell. 1995. Historical syntax in cross linguistic perspective. Cambridge: Cambridge University Press.

Hartmann, Katharina \& Malte Zimmermann. 2004. Focus strategies in Chadic: the case of Tangale revisited. In Shinichiro Ishihara, Michaela Schmitz \& Anne Schwarz (eds.), Interdisciplinary studies on information structure, 247-243. Potsdam: Universitätsverlag Potsdam.

Hartmann, Katharina \& Malte Zimmermann. 2007. Focus strategies in Chadic: The case of Tangale revisited. Studia Linguistica 61. 95-129.

Heine, Bernd \& Mechtild Reh. 1984. Grammaticalization and reanalysis in African languages. Hamburg: Helmut Buske.

Herring, Susan. 1990. Information structure as a consequence of word order type. Proceedings of the Sixteenth Annual Meeting of the Berkeley Linguistics Society, 163-174.

Hyman, Larry M. 1979. Nouns: A-forms (in focus). In Larry M. Hyman (ed.), Aghem grammatical structure, 16-27. Los Angeles: UCLA.

Hyman, Larry M. 1981. Noni grammatical structure. With special reference to verb morphology. California Occasional Papers in Linguistics 9.

Hyman, Larry M. 1985. Dependency relations in Aghem syntax: the mysterious case of the empty determiner in Aghem. Précis from the 15th Annual Conference on African Linguistics. Supplement 9 to Studies in African Linguistics. 151-156.

Hyman, Larry M. 1999. The interaction between focus and tone in Bantu. In George Rebuschi \& Laurice Tuller (eds.), The Grammar of Focus, 151-178. Amsterdam: John Benjamins.

Hyman, Larry M. 2010. Focus marking in Aghem: syntax or semantics? In Ines Fiedler \& Anne Schwarz (eds.), The expression of information structure: a documentation of its diversity across Africa, 95-116. Amsterdam: John Benjamins.

Hyman, Larry M. \& John Watters. 1984. Auxiliary focus. Studies in African Linguistics 15. 233-273.

Hyman, Larry M. \& Maria Polinksy. 2009. Focus in Aghem. In Caroline Féry \& Malte Zimmermann (eds.), Information structure. Theoretical, typological and experimental perspectives, 206-233. Oxford: Oxford University Press.

Jarvis, Elizabeth. 1991. Tense and aspect in Podoko narrative and procedural discourse. In Stephen C. Anderson \& Bernard Comrie (eds.), Tense and aspect in eight languages of Cameroon, 213-237. Dallas: SIL and University of Texas at Arlington.

Joswig, Andreas. 2015. Syntactic sensitivity and preferred clause structure in Majang. In Angelika Mietzner \& Anne Storch (eds.), Nilo-Saharan: Models and descriptions, 169-176. Cologne: Rüdiger Köppe Verlag.

Kalinowski, Cristin \& Jeff Good. 2014. Non-canonical head-marking of information structure in African languages. Talk given at Workshop on information structure in head-marking languages, Nijmegen, MPI.

Kasimir, Elke. 2005. Question-Answer test and givenness: some question marks. Working Papers of the SFB632, Interdisciplinary Studies on Information Structure (ISIS) 3. 1-52.

Kavari, Jekura U., Lutz Marten \& Jenneke van der Wal. 2012. Tone cases in Otjiherero: head-complement relations, linear order, and information structure. Africana Linguistica 18. 315-353.

Kidda, Mairo E. 1993. Tangale phonology. A descriptive analysis. Berlin: Reimer.

Kidwai, Ayesha. 1999. Word order and focus positions in universal grammar. In George Rebuschi \& Laurice Tuller (eds.), The grammar of focus, 213-244. Amsterdam: John Benjamins. 
Kim, Alan H.O. 1988. Preverbal focusing and type XXIII languages. In Michael Hammond, Edith A. Moravcsik \& Jessica Wirth (eds.), Studies in syntactic typology, 147-169. Amsterdam: John Benjamins.

King, Deborah. 2004. Structural and pragmatic functions of Kuki-Chin verbal stem alternations. Journal of the Southeast Asian Linguistics Society 1. 141-157.

Krifka, Manfred. 2007. Basic notions of information structure. In Caroline Féry, Gisbert Fanselow \& Manfred Krifka (eds.), Working Papers of the SFB 632, Interdisciplinary Studies on Information Structure, 13-55. Potsdam: Universitätsverlag Potsdam.

Lambrecht, Knud. 1994. Information structure and sentence form. Cambridge: Cambridge University Press.

Manfredi, Victor. 2005. Conjoint/disjoint in western Benue-Kwa. Talk given at Humboldt Universität, Berlin, and LUCL, Leiden.

Matić, Dejan \& Daniel Wedgwood. 2013. The meanings of focus: the significance of an interpretation-based category in a cross-linguistic perspective. Journal of Linguistics 49 (1). 1-37.

Meeussen, A. E. 1959. Essai de grammaire Rundi. Tervuren: Musée Royale de l'Afrique Central.

Megerdoomian, Karine. 2011. Focus and the auxiliary in Eastern Armenian. Talk given at BLS 2011 - languages of the Causasus.

Molnár, Valeria. 2002. Contrast - from a contrastive perspective. In Hilde Hasselgård, Stig Johansson, Bergljot Behrens \& Cathrine Fabricius-Hansen (eds.), Information structure in a cross-linguistic perspective, 147-162. Amsterdam: Rodopi.

Morimoto, Yukiko. This volume. This Kikuyu focus marker nĩ: formal and functional similarities to the conjoint/disjoint alternation.

Mous, Maarten. 1997. The position of the object in Tunen. In Rose-Marie Déchaine \& Victor Manfredi (eds.), Object positions in Benue-Kwa, 123-137. Den Haag: Holland Academic Graphics.

Muysken, Pieter. 1995. Focus in Quechua. In Katalin É. Kiss (ed.), Discourse configurational languages, 375-393. New York, Oxford: Oxford University Press.

Ndayiragije, Juvénal. 1999. Checking economy. Linguistic Inquiry 30. 399-444.

Neeleman, Ad, Elena Titov, Hans van de Koot \& Reiko Vermeulen. 2009. A syntactic typology of topic, focus and contrast. In Jeroen Van Craenenbroeck (ed.), Alternatives to Cartography, 15-52. Berlin: Mouton de Gruyter.

Nikolaeva, Irina. 2001. Secondary topic as a relation in information structure. Linguistics 39 (1). $1-49$.

Nshemezimana, Ernest \& Koen Bostoen. 2013. Alternance conjoint/disjoint en kirundi (JD62). Talk given at Workshop in information structure in Bantu, Berlin.

Nshemezimana, Ernest, \& Koen Bostoen. This volume. The conjoint/disjoint alternation in Kirundi (JD62): A case for its abolition.

Robert, Stéphane. 2010. Focus in Atlantic languages. In Ines Fiedler \& Anne Schwarz (eds.), The expression of information structure. A documentation of its diversity across Africa, 233-260. Amsterdam: John Benjamins.

Sabimana, Firmard. 1986. The relational structure of the Kirundi verb. Bloomington: Indiana University $\mathrm{PhD}$ thesis.

Samek-Lodovici, Vieri. 2005. Prosody-syntax interaction in the expression of focus. Natural Language \& Linguistic Theory 23. 687-755.

Schwarz, Florian. 2003. Focus marking in Kikuyu. ZAS Papers in Linguistics 30. 41-118.

Schwarz, Florian. 2007. Ex-situ focus in Kikuyu. In Enoch O. Aboh, Katharina Hartmann \& Malte Zimmermann (eds.), Focus strategies in African languages: The interaction of focus and grammar in Niger-Congo and Afro-Asiatic, 139-160. Berlin: Mouton de Gruyter. 
Sharma, Devyani. 2003. Discourse clitics and constructive morphology in Hindi. In Miriam Butt \& Tracy King (eds.), Nominals: inside and out, 59-84. Stanford, CA: SCLI.

Sharman, J. C. 1956. The tabulation of tenses in a Bantu language (Bemba: Northern Rhodesia). Africa 16. 29-46.

Slade, Benjamin Martin. 2011. Formal and philological inquiries into the nature of interrogatives, indefinites, disjunction, and focus in Sinhala and other languages. UrbanaChampaign: University of Illinois dissertation.

Smit, Niels. 2010. FYI. Amsterdam: University of Amsterdam PhD thesis.

Stiebels, Barbara. 2006. Agent focus in Mayan languages. Natural Language \& Linguistic Theory 24. 501-570.

Tamrazian, Arminé. 1991. Focus and wh-movement in Armenian. UCL Working Papers in Linguistics 3. 101-121.

Tonhauser, Judith. 2003. F-constructions in Yucatec Maya. In J. Menéndez-Benito Andersen \& Adam Werle (eds.), Proceedings of semantics of under-represented languages in the Americas II, 203-223. Amherst: UMASS.

Vallduví, Enric. 1992. The informational component. New York: Garland Publishing Inc.

Van der Wal, Jenneke. 2009. Word order and information structure in Makhuwa-Enahara. Utrecht: LOT.

Van der Wal, Jenneke. 2014. Morphological marking of term focus. Talk given at workshop Information structure in head-marking languages, Max Planck Institute, Nijmegen.

Van der Wal, Jenneke. 2016. Diagnosing focus. Studies in Language 40 (2). 259-301.

Van der Wal, Jenneke. To appear. Diagnosing focus. Studies in Language.

Van der Wal, Jenneke \& Jacky Maniacky. 2015. How 'person' got into focus: grammaticalisation of clefts in Lingala and Kikongo areas. Linguistics 53 (1). 1-52.

Van Valin Jr., Robert D. 1999. A typology of the interaction of focus structure and syntax. In Raxilina, E. \& J. Testelec (ed.), Typology and the theory of language: From description to explanation, 511-524. Moscow: Languages of Russian Culture.

Van Valin Jr., Robert D. 2009. Information structure in Banawá, Wari' and Karitiâna: an overview. Report to US National Science Foundation.

Vapnarsky, Valentina. 2013. Is Yucatec Maya an omnipredicative language? Predication, the copula and focus constructions. Sprachtypologie und Universalienforschung 66 (1). 40-86.

Verhoeven Elisabeth \& Stavros Skopeteas. 2015. Licensing focus constructions in Yucatec Maya. International Journal of American Linguistics 81 (1). 1-40.

Voeltz, F.K.E. 2004. Long and short verb forms in Zulu. Ms., University of Cologne.

Watters, John. 1979. Focus in Aghem. In Larry M. Hyman (ed.), Aghem grammatical structure, 137-198. Los Angeles: University of Southern California.

Yip, Moira. 2004. Phonological markedness and allomorph selection in Zahao. Language and linguistics 5 (4). 969-1001.

Zerbian, Sabine. 2007. Phonological phrasing in Northern Sotho (Bantu). The Linguistic Review 24 (2-3). 233-262.

Zimmermann, Malte. 2011. The grammatical expression of focus in West Chadic: Variation and uniformity in and across languages. Linguistics 39 (5). 1163-1213.

Zimmermann, Malte \& Edgar Onea. 2011. Focus marking and focus interpretation. Lingua 121 (11). 1651-1670.

Zubizarreta, Maria Luisa. 1998. Prosody, focus, and word order. Cambridge, MA: MIT Press. 